\title{
MOLECULAR EVOLUTION OF GPCRS Secretin/secretin receptors
}

\author{
Janice K V Tam, Leo T O Lee, Jun Jin and Billy K C Chow
}

School of Biological Sciences, The University of Hong Kong, Pokfulam Road, Hong Kong, Hong Kong

Correspondence should be addressed to B K C Chow Email bkcc@hku.hk

\begin{abstract}
In mammals, secretin is a 27-amino acid peptide that was first studied in 1902 by Bayliss and Starling from the extracts of the jejunal mucosa for its ability to stimulate pancreatic secretion. To date, secretin has only been identified in tetrapods, with the earliest diverged secretin found in frogs. Despite being the first hormone discovered, secretin's evolutionary origin remains enigmatic, it shows moderate sequence identity in nonmammalian tetrapods but is highly conserved in mammals. Current hypotheses suggest that although secretin has already emerged before the divergence of osteichthyans, it was lost in fish and retained only in land vertebrates. Nevertheless, the cognate receptor of secretin has been identified in both actinopterygian fish (zebrafish) and sarcopterygian fish (lungfish). However, the zebrafish secretin receptor was shown to be nonbioactive. Based on the present information that the earliest diverged bioactive secretin receptor was found in lungfish, and its ability to interact with both vasoactive intestinal peptide and pituitary adenylate cyclase-activating polypeptide potently suggested that secretin receptor was descended from a VPAC-like receptor gene before the Actinopterygii-Sarcopterygii split in the vertebrate lineage. Hence, secretin and secretin receptor have gone through independent evolutionary trajectories despite their concurrent emergence post-2R. A functional secretin-secretin receptor axis has probably emerged in the amphibians. Although the pleiotropic actions of secretin are well documented in the literature, only limited information of its physiological functions in nonmammalian tetrapods have been reported. To decipher the structural and functional divergence of secretin and secretin receptor, functional characterization of the ligandreceptor pair in nonmammals would be the next perspective for investigation.
\end{abstract}
Key Words
- secretin
- secretin receptor
- evolution
- origin
- divergence

Journal of Molecular Endocrinology (2014) 52, T1-T14

\section{Discovery of secretin: concept of hormones and first physiological function}

Secretin was first discovered by Bayliss and Starling in 1902 from the extracts of the jejunal mucosa for its ability to stimulate pancreatic secretion (Bayliss \& Starling 1902). They introduced the concept of hormones as chemical messengers released from cells and conveyed by the blood stream to the target organ(s) to stimulate secretion by means of chemical reflex (Modlin \& Kidd 2001).
'Hormone' was derived from the Greek phrase 'I arouse to excitement', and with this novel concept more than a 100 years ago, Bayliss and Starling established the discipline of endocrinology. Since its discovery, it took more than 60 years until SCT peptide was isolated and characterized. Secretin was first purified from the porcine intestine and was found to be a basic 27-amino acid peptide (Jorpes \& Mutt 1961, Mutt et al. 1970). Later, SCT peptide or derived sequences from cDNAs was

Published by Bioscientifica Ltd.

This paper is one of eight papers that form part of a thematic review section on the Molecular Evolution of GPCRs. The Guest Editor for this section was Hubert Vaudry $y_{10}: 06: 41 \mathrm{AM}$ European Institute for Peptides Research, University of Rouen, France. via free access 
characterized from various vertebrates, including chicken (Nilsson et al. 1980), bovine (Carlquist et al. 1981), humans (Carlquist et al. 1985), dog (Shinomura et al. 1987), rat (Kopin et al. 1991), guinea pig (Buscail et al. 1990), rabbit (Gossen et al. 1990), sheep (Bounjoua et al. 1991), Xenopus laevis, and Rana rugulosa (Tam et al. 2011).

\section{Structural evolution of secretin}

\section{Secretin as a member of the secretin/glucagon family}

Secretin is a member of the secretin/glucagon superfamily which includes a pleiotropic group of brain-gut peptides that share significant structural and conformational homology, with affinity for the secretin/glucagon receptor superfamily of the secretin G protein-coupled receptor (GPCR) family (Ng et al. 2002, Siu et al. 2006, Cardoso et al. 2010). Both sequence and secondary structure of the secretin/glucagon superfamily peptides are highly conserved, in which the latter consists of a random N-terminal structure and a C-terminal alpha helix (Wray et al. 1998, Bourgault et al. 2009).

Currently, ten peptides belonging to the superfamily have been isolated in humans, including pituitary adenylate cyclase-activating polypeptide (PACAP), PACAP-related peptide (PRP), vasoactive intestinal peptide (VIP), peptide histidine isoleucine (PHI)/peptide histidine methionine (PHM), growth hormone-releasing hormone (GHRH), secretin (SCT), glucagon (GCG), glucagon-like peptide 1 (GLP1), glucagon-like peptide 2 (GLP2), and glucose-dependent insulinotropic peptide (or gastric inhibitory polypeptide (GIP)) (Cardoso et al. 2010). In the superfamily, vertebrate secretin demonstrates the lowest sequence conservation. Revealed by sequence and phylogenetic analyses, PACAP; VIP; and GCG are the most conserved members, while PRP; GLP2; and SCT are the most divergent (Cardoso et al. 2010).

\section{Secretin has moderate sequence identity in nonmammalian vertebrates but is highly conserved in mammals}

Figure $1 \mathrm{~A}$ shows the alignment of the mature peptide of secretin from all the vertebrate species hitherto identified and isolated. Turkey and zebra finch predicted sequences were included because of the limited number of nonmammalian tetrapod secretin sequences in the literature. Secretin is highly conserved among the mammalian species (81.5-96.3\%) (Fig. 1B). In contrast, when nonmammalian secretins are compared with mammalian
A

Human
Pig
Sheep
Cattle
Guinea pig
Dog
Rabbit
Rat
Mouse
Chicken
Zebra finch*
Turkey*
X. laevis
R. rugulosa
X. tropicalis

B

\begin{tabular}{|c|c|c|c|c|c|c|c|c|c|}
\hline & Human & $\begin{array}{c}\text { Pig/ } \\
\text { sheep/ } \\
\text { cattle/ } \\
\text { guinea pig }\end{array}$ & Dog & Rabbit & Rat & Mouse & $\begin{array}{l}\text { Chicken/ } \\
\text { zebra finch/ } \\
\text { turkey }\end{array}$ & $X$. laevis & $\begin{array}{l}\text { R. rugulosa } \\
X \text {. tropicalis }\end{array}$ \\
\hline Human & $\ldots$ & 92.6 & 96.3 & 85.2 & 88.9 & 85.2 & 51.9 & 39.3 & 39.3 \\
\hline $\begin{array}{l}\text { Pig/sheep/ } \\
\text { cattle/ } \\
\text { guinea pig }\end{array}$ & & -- & 96.3 & 88.9 & 96.3 & 92.6 & 51.9 & 42.9 & 42.9 \\
\hline Dog & & &.- & 85.2 & 92.6 & 88.9 & 51.9 & 42.9 & 42.9 \\
\hline Rabbit & & & & $\ldots$ & 85.2 & 81.5 & 48.1 & 39.3 & 39.3 \\
\hline Rat & & & & & $\cdots$ & 96.3 & 48.1 & 39.3 & 39.3 \\
\hline Mouse & & & & & & ... & 48.1 & 39.3 & 42.9 \\
\hline $\begin{array}{l}\text { Chicken/ } \\
\text { Zebra finch/ } \\
\text { Turkey }\end{array}$ & & & & & & & $\cdots$ & 46.4 & 46.4 \\
\hline X. laevis & & & & & & & & -.. & 96.4 \\
\hline $\begin{array}{l}\text { R. rugulosa/ } \\
\text { X. tropicalis }\end{array}$ & & & & & & & & & -- \\
\hline
\end{tabular}

\section{Figure 1}

(A) Alignment of secretin mature peptides. Accession numbers are human Homo sapiens, AAG31443; sheep Ovis aries, P31299; rat Rattus norvegicus, AAA42128; domestic guinea pig Cavia porcellus, P63297; mouse Mus musculus, CAA51982; cattle Bos taurus, P63296; dog Canis lupus familiaris, P09910; rabbit Oryctolagus cuniculus, P32647; pig Sus scrofa,

AAA31121; chicken Gallus gallus, P01280; zebra finch Taeniopygia guttata, ENSTGUT00000007450; turkey Meleagris gallopavo, ENSMGAT00000004169; African clawed frog Xenopus laevis, NP_001267540; bullfrog Rana rugulosa, ADT91712. *Predicted sequence from Ensembl.org. (B) Percent amino acid sequence identity of the aligned secretin mature peptides.

secretins, the sequence identity drops to $39.3-51.9 \%$ (Fig. 1B). Interestingly, comparison of the sequence identity of secretins in nonmammalian tetrapods reveals that avian secretins only share limited sequence identity with frog secretins (46.4\%). It suggests that secretin evolved relatively rapidly along the tetrapod lineage until the divergence of mammals, during which its sequence was under a stringent evolutionary pressure.

As shown in Fig. 1A, SCT peptides maintained well-preserved loci of biological activity in their $\mathrm{N}$-terminal domains. Asp at position 3 is conserved across all the mature SCT peptides and this residue has a role in adenyl cyclase (AC) stimulation and interacts with the basic residues in the second transmembrane (TM) helix of the secretin GPCRs (Cardoso et al. 2010). Other conserved residues such as His1 and Phe6 are key amino acids in secretin's GPCR-binding affinity (Gourlet et al. 1991,

Published by Bioscientifica Ltd 

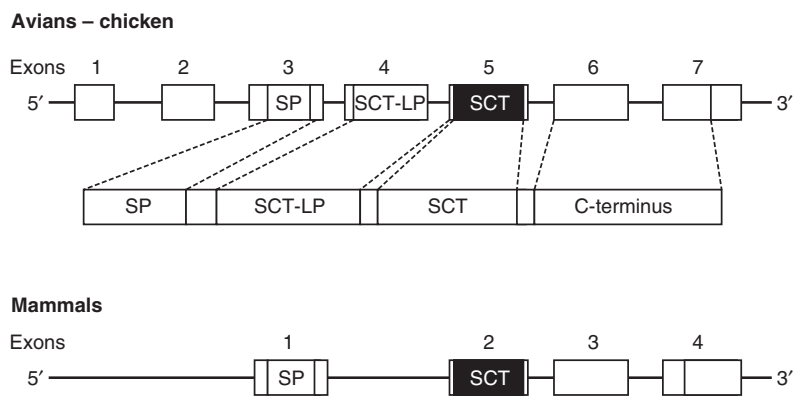

Figure 2

Comparison of gene organizations of secretin in avians and mammals. The exons are shown as boxes and the introns as lines. The lengths of the exons and introns are not drawn to scale so that they can be aligned between genes.

Gallwitz et al. 1994, Irwin 2001, Bourgault et al. 2009). Predicted from the conserved GKR (Gly-Lys-Arg) cleavage site in the secretin precursors, secretin is a 27 -amino acid peptide except in frog (Tam et al. 2011). In avians, in addition to the secretin peptide, a secretin-like peptide with a predicted length of 34-amino acids has been reported. The chicken secretin-like peptide shares 56 and $52 \%$ sequence identity to chicken and mammalian secretin respectively (Wang et al. 2012). According to the Ensembl zebra finch and turkey genomes, the predicted zebra finch and turkey secretin precursors also contain two peptides: secretin and secretin-like, which share high amino acid sequence identity to chicken secretin $(100 \%)$ and secretinlike (88 or $100 \%)$ respectively (Wang et al. 2012).

\section{Secretin genes in mammals and nonmammalian vertebrates}

There is a remarkable difference between the genomic organizations of SCT in mammals and chicken (Fig. 2). In mammals, the human and rat SCT genes consist of four exons spanning 713 and 813 nucleotides, respectively, and exon 2 encodes the SCT peptide (Kopin et al. 1991, Sherwood et al. 2000, Whitmore et al. 2000). The SCT gene is most conserved within the exon that encodes the biologically active mature SCT peptide, i.e. exon 2 (Whitmore et al. 2000). In chicken, the SCT gene consists of seven exons, exons 1 and 2 are noncoding, exon 4 encodes the secretin-like peptide, and exon 5 encodes the mature secretin peptide. It was proposed that the extra exon found in avian species (chicken, turkey, and zebra finch) is either due to an avian-specific exon duplication event (Hwang et al. 2013), or it was originated from a duplication of the VIP gene that was retained in avians but lost in mammals (Wang et al. 2012).

\section{Molecular evolution of secretin}

In mammals, the members of the secretin/glucagon superfamily are encoded by six genes (ADCYAP1, GHRH, VIP, GCG, SCT, and GIP) (Fig. 3; Sherwood et al. 2000, Lee et al. 2007). Although it has not been possible to determine the precise timing of the emergence of these genes, they are proposed to have evolved from a primordial exon via exon and gene/chromosome duplications during the chordate radiation (Fig. 3), since they are absent in nonvertebrate genomes including Caenorhabditis elegans, amphioxus, and Ciona (Cardoso et al. 2010, Hwang et al. 2013). Their divergence was postulated to take place after the protostome-deuterostome split from the primordial exon, which was part of an existing gene or gene fragment generated by rounds of gene/genome duplication. Originated from the duplicate exon under different evolutionary pressures, the chordate PACAP-like and glucagon-like subfamilies emerged (Cardoso et al. 2010; Fig. 3).

\section{When did secretin emerge?}

The PACAP-like subfamily is hypothesized to begin with a $P A C A P$-like gene more than $650 \mathrm{MYA}$. From this primordial gene, the ancestral PRP-PACAP was generated by exon duplication. On the basis of the current theory that two rounds of genome duplication $(1 \mathrm{R} / 2 \mathrm{R})$ have taken place before the Sarcopterygii-Actinopterygii split (Ohno 1970, Steinke et al. 2006, Ogino et al. 2009), four paralogous genes were generated, in which three of them, PRP-PACAP, $P H I-V I P$, and GHRH were retained in the genome and passed on along the vertebrate lineage (Cardoso et al. 2010). For secretin, its evolutionary origin remains elusive because it is more divergent from other members of the PACAP-like subfamily, and has only been identified in tetrapods at present (Cardoso et al. 2006, 2010, Hwang et al. 2013). To add clues to find the origin and divergence time of secretin, we have summarized the comparative chromosomal synteny analyses of secretin previously reported with updates from current genome versions (Fig. 4).

In mammals, SCT is found in all representative species and has a highly conserved genome environment as shown by the neighboring genes DRD4, DEAF1, IRF7, and PNPLA2 (Fig. 4). In avians, SCT has been identified from chicken Gallus gallus, zebra finch Taeniopygia guttata, and turkey Meleagris gallopavo. Although an avian-specific exon duplication that generated the secretin-like peptide has been proposed to have taken place (Wang et al. 2012), the gene environment of secretin is highly syntenic within

Published by Bioscientifica Ltd 


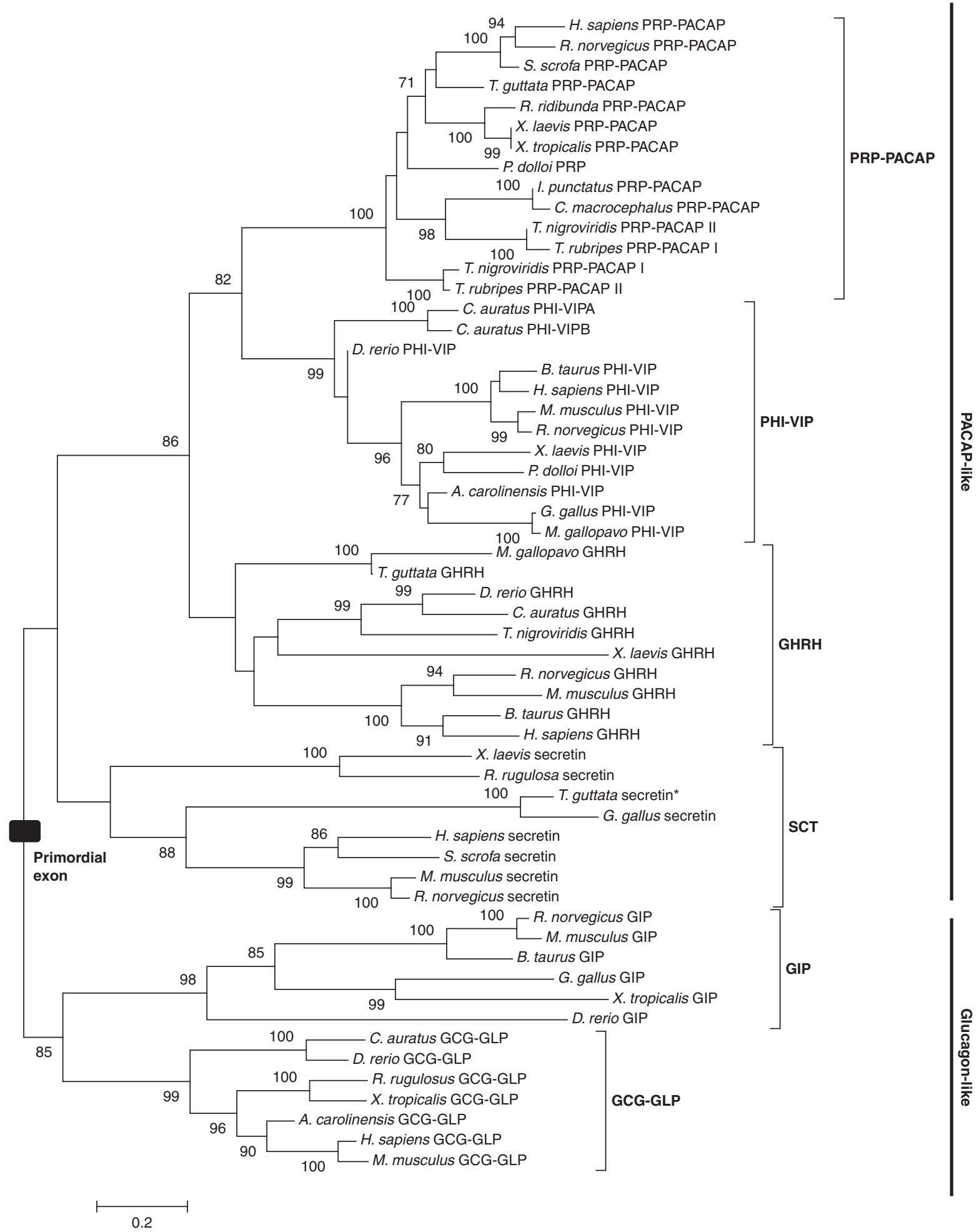

Figure 3

Phylogenetic analysis of the secretin/glucagon hormone precursor superfamily. The tree was generated by maximum likelihood (ML) and plotted by MEGA 5.0. Predicted sequences are marked by asterisk. SCT, secretin precursor; preproGHRH, prepro-growth hormone-releasing hormone;
PHI-VIP, peptide histidine isoleucine-vasoactive intestinal peptide precursor; PRP-PACAP, pituitary adenylate cyclase-activating polypeptide (PACAP)-related peptide-PACAP precursor. The proposed primordial exon is represented by a black rectangle.

Published by Bioscientifica Ltd 


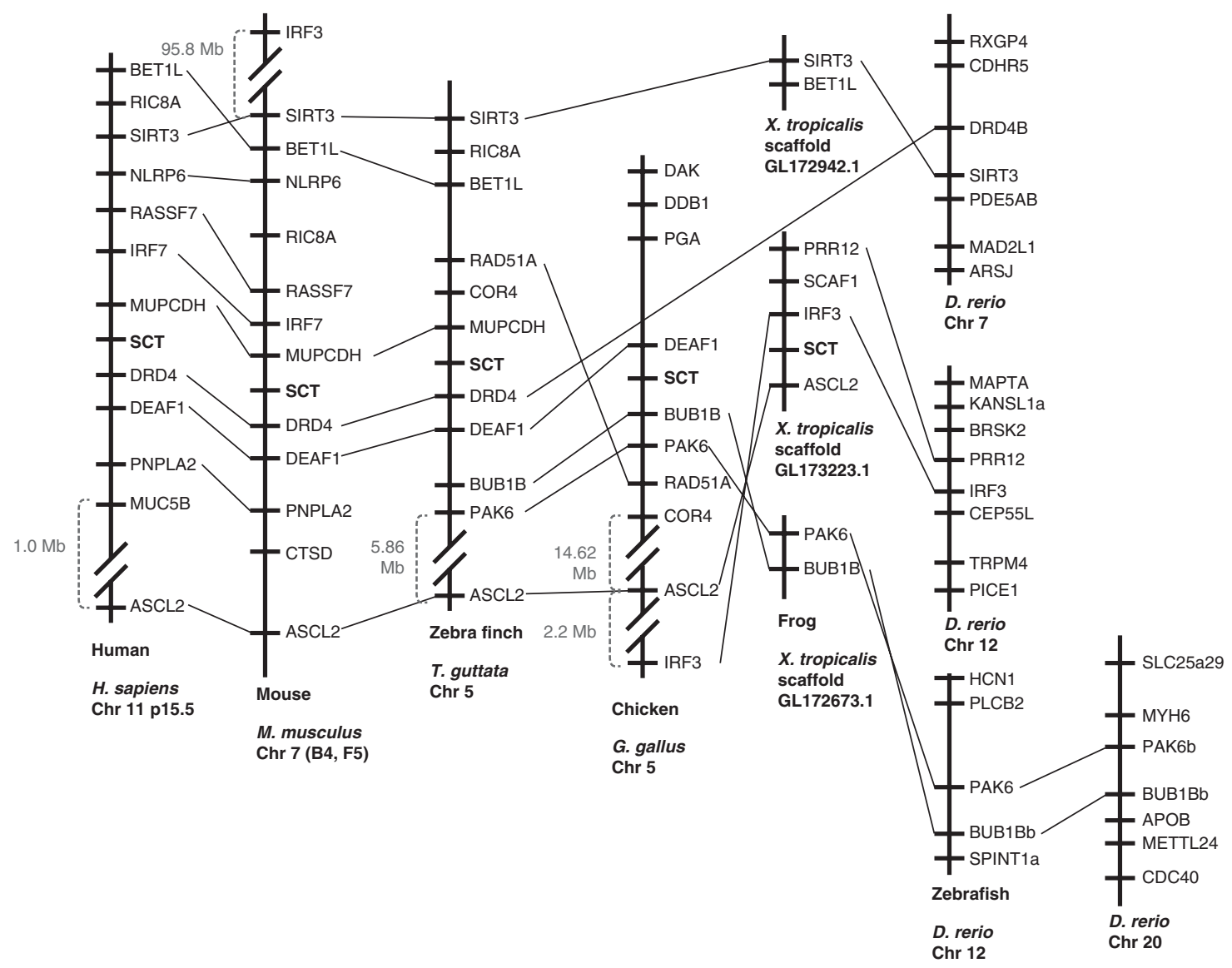

\section{Figure 4}

Chromosomal locations of SCT genes in various vertebrate species. Neighboring genes of SCT in different vertebrate genomes are shown. Homologous genes in proximity of secretin are linked by straight lines to demonstrate the syntenic gene environment of SCT in the analyzed

avians as well as from avians to mammals (Fig. 4). However, using the latest version of the anole lizard genome (AnoCar2.0), a secretin-like sequence could not be identified. The absence of secretin in anoles is likely due to either incomplete genome assembly or the loss of this gene in this species (Hwang et al. 2013). To date, the earliest diverging secretin found is in amphibians represented by the frog species X. laevis, Xenopus tropicalis, and R. rugulosa (Tam et al. 2011). In contrast to the highly syntenic gene environment in mammals and avians, secretin in frogs (represented by $X$. tropicalis) has a relatively less conserved gene order in vicinity. It could be attributed to the incomplete nature of the genome assembly, but it may also represent an earlier chromosomal arrangement of secretin and the genes in proximity. In the Actinopterygii lineage, teleost is the most diverse vertebrate clade (Cardoso et al. 2010). Although, secretin-like sequences have not been found in any available teleost genomes Printed in Great Britain vertebrate species. Note that sct is not found in zebrafish genome. Versions of genome databases at Ensembl: human (GRCh37), mouse (GRCm38), zebra finch (taeGut3.2.4), chicken (Galgal4), Xenopus tropicalis (JGI_4.2), and zebrafish (Zv9).

(fugu, medaka, zebrafish, teraodon, and stickleback), a secretin receptor has been identified in zebrafish (Wang et al. 2012). Hence, it has been proposed that secretin does not exist in teleost fish (Tam et al. 2011, Wang et al. 2012) and may be a result of local gene duplications or gene loss that are proposed to have occurred after 2R duplication but before the divergence of teleosts and tetrapods (Hwang et al. 2013). For sarcopterygian fish, lungfish and coelacanth are the only extant species at present (Bailes et al. 2007). Although our group has previously cloned a functional secretin receptor from lungfish Protopterus dolloi, we did not find any secretin-like sequence that could be a potential endogenous ligand for this secretin receptor. However, we cannot exclude the possibility that a secretinlike peptide exists in other lungfish species and lobe-finned fish species (e.g., coelacanth).

For agnathans, the first lamprey VIP/PACAP ligands were identified from the Japanese lamprey (Ng et al. 2012).

Published by Bioscientifica Ltd 
However, it has been reported that secretin was not found in the sea lamprey, Petromyzon marinus, which is an extant primitive vertebrate of the Agnatha clade (Cardoso et al. 2010). Although it could be attributed to the incomplete nature of the genome assembly, suggested by the absence of secretin in both teleosts and sarcopterygian fish species, it is a more plausible explanation that secretin is absent in agnathans. Consistent with this theory, no secretin-like peptide could be identified in extensive genome searches in any early deuterostomes (e.g., urochordates). Although it has been previously reported that secretin-like peptides have been detected by immunohistochemistry in Ciona intestinalis, Styela plicata, and Branchiostomata, secretinlike peptides have never been isolated and sequenced from these animals (Cardoso et al. 2010).

Integrating the current information, we propose that, descended from the primordial exon (Fig. 3), the first ancestral $P A C A P /$ secretin-like gene could have appeared in pre- or early vertebrates before the two rounds of wholegenome duplications occurred (Hwang et al. 2013). After a series of chromosomal translocations and/or rearrangements in early vertebrates, this ancestral PACAP/secretinlike gene went through the two rounds of genome duplication before the Sarcopterygii-Actinopterygii split, which generated four copies of this ancestral gene. One of the four copies was eventually established as the SCT gene after local gene duplication and/or loss before the divergence of teleosts and tetrapods (Hwang et al. 2013). Hence, in this proposed evolutionary scheme, secretin is hypothesized to have emerged before the divergence of teleosts and tetrapods but was lost in teleosts and retained only in land vertebrates, explaining why the SCT gene is absent in teleosts as well as sarcopterygian fish.

\section{Molecular evolution and structural features of secretin receptor}

To understand the evolutionary trajectory of the secretin receptor in the secretin GPCR family, sequences from mammals, chicken, $X$. laevis, lungfish, and zebrafish were analyzed with all the available full-length receptors cloned and obtained from data mining in the PACAP-like receptor subfamily (PAC1, VPAC1, VPAC2, GHRHR, and PRPR) (Fig. 5). On the basis of previous analyses that the receptors for VIP, PACAP, GHRHR, PRP, and SCT are descended from a PACAP-like receptor ancestral gene after the initial divergence of the glucagon-like and PACAP-like branches in the secretin GPCR family (Laburthe et al. 1996, Chow et al. 1997, Chan et al. 1998, Cardoso et al. 2010), only the PACAP-like receptors have been included in the

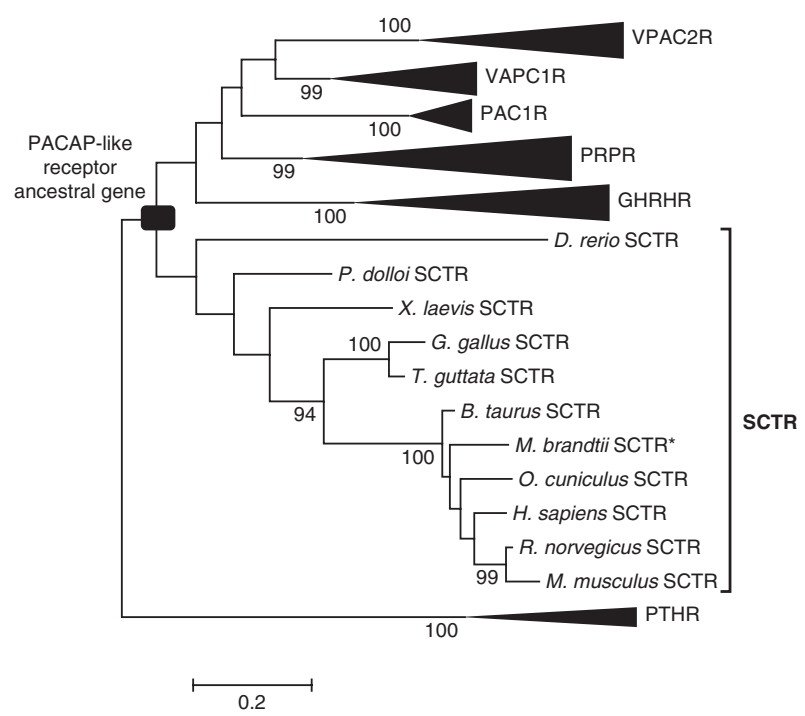

\section{Figure 5}

Phylogenetic analysis of the secretin receptor superfamily. The predicted sequence from genome project is marked by an asterisk. Other receptor sequences used in the present analysis are referenced (Cardoso et al. 2006, $\mathrm{Ng}$ et al. 2010, Wang et al. 2012, Hwang et al. 2013).

analysis (Fig. 5). The phylogenetic tree was generated by ClustalW alignment using the maximum-likelihood (ML) method with the parathyroid hormone receptors (PTHR) as outgroup. The tree grouped the PACAP-like receptors into six major clades (SCTR, GHRHR, PRPR, PAC1, VPAC1, and VPAC2), each of which contains orthologous receptors from different vertebrate species. The monophyly of each receptor clade was strongly supported by the bootstrap values (94-100) (Fig. 5). The overall topology of the tree is in agreement with previous reports (Segre \& Goldring 1993, Tam et al. 2011). Phylogenies inferred from the SCTR clade are consistent with the established divergence of vertebrate groups, with lungfish and zebrafish SCTRs most distantly related to the mammalian SCTR sub-branch, demonstrating the gradual divergence of secretin receptors along the Osteichthyes lineage until the emergence of mammalian secretin receptors, during which the receptors were more structurally stabilized.

To reveal the relationship between the structural features and the evolution of SCTR, we summarized the key structural features together with the conservation score in Fig. 6. To minimize potential bias in the conservation score analysis toward mammalian secretin receptors, only one sequence from each vertebrate group was used in the alignment (mammals: human, amphibian: $X$. laevis, avian: chicken, sarcopterygian fish: $P$. dolloi, and teleost: zebrafish).

Published by Bioscientifica Ltd 


\begin{tabular}{|c|c|c|c|c|c|}
\hline \multirow{2}{*}{ H_sapienaSCTR } & $\ldots \ldots \ldots 10$ & $\ldots \ldots 20$ & \multicolumn{3}{|c|}{$\ldots \ldots{ }^{30} \ldots \ldots .40 \ldots 50$} \\
\hline & PPI & QQLLLPVIIA & CAAHSTGALP & RLCDVLQVIW & EEQDQCLQEI \\
\hline & & RLAVAAFIL & RVCSQVCAVP & ECDLDVLIL & EEETCHNII \\
\hline SCTR & $=--M$ & TISVIIFWI & SAVII-RAVP & VCDLLNVLK & EEENCAEII \\
\hline CTR & $-\cdots-M T T S D$ & พLWSTGIพAL & ALLLRPAAAQ & LSCDLLRVLK & MQEDLCTEAL \\
\hline CTR & MFLELRVVFK & WIALSLCL & ENIILIHAVH & IECELPS I LK & EKEQCFNIL \\
\hline \multirow[t]{2}{*}{ Consistency } & 010023213 & 254525426 & $3443322 * 64$ & $38 \cdot 4$ & $58773 \cdot 2549$ \\
\hline & \multicolumn{5}{|c|}{ L-.---. } \\
\hline CTR & SREQTGDLGT & EQ- PVPGCE & GMWDNISCWP & S SVPGRMVEV & ECPRFLRMLT \\
\hline OSCTR & RKQENRTES-- & S S--TнTGCS & ALWDDLNCWP & RAEAGETVSQ & PCPSFLRVK- \\
\hline CTR & SLEARNRTPA & DDLISS S R CA & GMWDNMSCWP & SSAVGYTVSA & HCPKFFQMLT \\
\hline & A A ENVSRNYW & DEGG & GKWDKI SCWP & SSALGETVTI & PCPEILQGFT \\
\hline TR & SAEAHNRSEN & QE- - QA GCA & GEWDNVT TWP & SAAVRQTVSV & PCPEFISLLT \\
\hline \multirow[t]{2}{*}{ Conststency } & 64.4355411 & 33003336.4 & $74 \cdots 676 \ldots$ & $7754647 \div 65$ & $4-* 5775456$ \\
\hline & \multicolumn{5}{|c|}{ *.... } \\
\hline CTR & SRNGSLFRNC & TQDGWSETFP & RPNLRCG- - & --- VNVNDSS & NEKRHSYLLK \\
\hline SCTR & $\mathrm{R}---\mathrm{GA}$ VMKNC & TENGWSVTFP & PYELA CGHGL & NDSFH & VLVSDEYFFY \\
\hline & GKQGFVYRNC & TSEGWSDPY & RPDIACG- & --- YNVNDTT & NEARRSYFMT \\
\hline & DQQGSLYRNC & TKDGWSTRFP & SIDVACG & $---\mathrm{YD}---\mathrm{AN}$ & ITDNVVYFMH \\
\hline CTR & GVKDFIYRNC & TINGWSEAFP & RLET & --- YKVNDTT & TDDKTSYYSN \\
\hline \multirow[t]{2}{*}{ Consistency } & & & & & $333525 * 643$ \\
\hline & \multicolumn{5}{|c|}{ 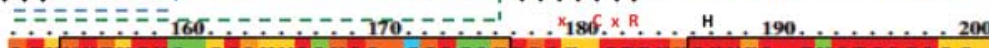 } \\
\hline & I. KV $\sqrt{M Y T V G Y S}$ & SSLVMILVAL & GIICAFRRIH & CTRNYIHMHL & FVSFILRALS \\
\hline & RVKIMYSAGYA & VsIVsIsIXI & TVICVFR R H & СТRАनІНMQL & FISFILRALF \\
\hline ETR & LXTMXTIGXC & TSIVTITIAL. & VVIASIRRIR & CTRNYI ВMEL & FTSFILRASS \\
\hline TR & LKTLYTAGYG & TSLASLA LAL & $A L L A S F R R I R$ & CTRNYI & EVSFILRAMS \\
\hline & I. KTMYTGYS & TSFLSLSVAV & IIIGFF|RKIR & СTRNYI НMAL & FTSEILRALS \\
\hline \multirow[t]{2}{*}{ Consistency } & $8=68 \cdot 86 \cdot * 4$ & $6.766 .58 \cdot 8$ & $38 \cdot 447 \cdot 8=6$ & $-3-\operatorname{sic}-3$ & $\because 5 \ldots \ldots+66$ \\
\hline & \multicolumn{4}{|c|}{$\ldots \ldots \ldots 220 \ldots \ldots$} & \\
\hline H_sapiensSCTR & NFIKDAVLFS & SDDVTYCDAB & - RAGCKLVMV & LFQY & 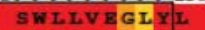 \\
\hline LSCTR & RIFIRDA AI:HY & SQEYYHCNSH & P PGCKVALF & LSNYC & SWLLVEAHY|L \\
\hline & NFIKDNVLFS & SEDTNYCDAY & $-T A G C K L T M V$ & FFQYC & SWLLVEGLYL \\
\hline IRR & IFIKDAVLYS & TEDINHCNIY & -STDCSFLMI & FFe Xe? & LVEGLYYL \\
\hline TR & VIIKDSVLFS & SKDIDHCSAY & AsscCKFVVV & $\mathbf{F} \times \mathbf{Q} \times \mathrm{C}$ & SWLLVEGLYL \\
\hline Cons & $47 * 8 * 68 * 66$ & $868537 \mathrm{ELI}^{667}$ & $0457: 75577$ & $657 \cdots+88 *$ & $\cdots \cdots * \cdots 76 *$ \\
\hline & & & & -3 & $\overline{300}$ \\
\hline TR & TLIA ISFFS & ERKYIQGFVA & FGWGSPAIFV & 共司工 & EDVGCWDINA \\
\hline SC? & RHSLINLSLRS & QKKRLHYIL & LGWGIPMLII & ISWSI & QNEGCWETRD \\
\hline & HSLLVISFFS & ERRFIWWF IA & LGK GAPTVFV & AA $1 \mathrm{AT}$ & ENVGCWDVNT \\
\hline & HTLLVISFFS & EWKYFCWYIA & LGWGSPLVFI & I A NA & ENIGCWDINS \\
\hline & HSLLVISFFS & ERRY FW WY IT & LGW LPSVFI & IAWS & EDIGCWDINI \\
\hline Consistency & $* 7=9 \underset{1062}{5} \cdot 76 *$ & $85 \cdot 5626895$ & $7 * * 4=4879$ & 66.7678573 & $876 \cdots{ }_{\mathrm{ECl} 2} 373$ \\
\hline & &. & $\therefore$ & -34 & $\because \ldots 350$ \\
\hline :TR & NASI WWIIRG & PVILSILFNF & ILFINILRIL & MRKIRTQE-T & RGNQVSHYKR \\
\hline & R日 GW I WW ILRV & VIIFITVNM & LFPLSIIREL & VGKIK: & H GNE INHHRK \\
\hline & NA KTWWIIRG & PVVASTFVNF & ILFVDILRIL & MRKLSS & S SDFNQYKR \\
\hline & NAS IWWIIRG & PVILSIFINF & ILFVRIIRIL & MKKIKATDVVV & SRNDFGQYKR \\
\hline & NAE IWWIIKG & PIILSIFINF & ILFVSIIRI & IKKIKTPD $=\mathrm{V}$ & FNQYKR \\
\hline & $7737 \ldots 986$ & $* 9966 * 57 * 7$ & $97 * 84$ & $75 * \cdot 6$ & 5575666888 \\
\hline & La kys TL2: & $10=1 \mathrm{r}=$ & & ELA & LGSFQGLVVA \\
\hline (2) & RAKSTFLLVS & LFGLQYVIFA & FFPDRVSVIT & FKIWNVIELA & LASTQGFIVA \\
\hline & LA K/STLLLIP & LFGVHYIIYA & FFPEDASSGT & MEIOLFFELA & LGSFQGFVVA \\
\hline & LA R STLLLIP & LFGV & FFPEDVSSGT & VEIRLSFEIT & LGSFQGFVVA \\
\hline & LA KfsTLIIP & LFGVBXITFT & IFPEEVSAVT & AEIRLYVEIA & VCSFQGFVVA \\
\hline & $* * 8[* * 7 * * 97$ & $\cdots 87 \cdot 76 \cdot 7$ & $76 \cdot 85463 \mathrm{ECl}^{7}$ & $48 \cdot 46$ & $87 \cdot 6 * 7,9 * \cdots$ \\
\hline & $\ldots \ldots \ldots .41$ & 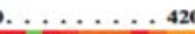 & & & \\
\hline & VIYCFLAGEV & QLEVQKKWQQ & LHP & $\mathbf{K} \mathbf{A}$ & QGT \\
\hline SSCTR & RLL XCF LNGEV & QYEVQRRWRR & WRLKQHFHGE & PRV В & SGLP-LTQVS \\
\hline & I LXCFLNGEV & QLEVQF & $\mathrm{L}=-$ & $3 \mathrm{As}$ & EM \\
\hline & VLXCELNGEV & & FLL- & ivs & 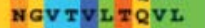 \\
\hline & VLYCELAGEV & Qse & FDVD & TTS & $g \mathrm{MT}$ \\
\hline & $8 \cdots \cdots \cdots$ & 1.87 & 11 & 446 & 7633158 \\
\hline & & & & & \\
\hline & & & & & \\
\hline & RLLTRPNTQIT & $\cdots-\cdots$ & & & \\
\hline & QVTKASPPQD & RKATPQRSSI & 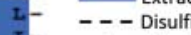 & e b & \\
\hline x-1a & PVSRSSNKEQ & RNTPAQKTSV & * Pote & tial si & \\
\hline P_dc & $\begin{array}{l}\text { LLTRSSPKDQ } \\
2586452322\end{array}$ & $\begin{array}{l}\text { RKSFDHSLAE } \\
3110011121\end{array}$ & $\begin{array}{l}\mathrm{K} Y \\
1.0\end{array}$ & & \\
\hline
\end{tabular}

\section{Figure 6}

Alignment of the amino acid sequences of secretin receptors in post-2R vertebrates. The conservation scoring is performed by PRALINE. The score ranged from zero (unconserved) to ten (most conserved) and represented with the color assignment from blue to red. Homo sapiens human, Danio rerio zebrafish, Gallus gallus chicken, Xenopus laevis African clawed frog, and Protopterus dolloi lungfish.

Published by Bioscientifica Lto 


\section{Ligand-binding domain}

The secretin/glucagon superfamily peptides interact in a bivalent mode with their receptors. It is believed that the $\mathrm{N}$-terminal receptor domain is involved in the ligands C-terminus binding, while the juxtamembrane domain and extracellular loops (ECLs) interact with the $\mathrm{N}$-terminus of the ligand. Therefore, the secretin GPCR $\mathrm{N}$-terminal extracellular domain has a defined common pattern of folding for ligand binding. This folding relies on the seven conserved cysteine residues and the specific aspartic acid (Asp53), tryptophan (Trp58), proline (Pro72), glycine (Gly93), and tryptophan (Trp94) residues (position based on the alignment) at the extracellular domain (Furness et al. 2012). These residues are conserved in all the known secretin receptor sequences. Apart from the first cysteine residue (Cys11) that exists as a free residue, the 2 nd to 7 th residues form three disulfide bonds as follows: 1-4 (Cys25-Cys71), 2-5 (Cys48-Cys89), and 3-6 (Cys57-Cys105). This suggests that the extracellular domain-binding pocket for the ligand secretin was well defined since the emergence of secretin receptor. The short sequence (six residues) insertion and deletion (four residues) in the zebrafish secretin receptor at the ECD may explain its failure to interact with any SCT peptides because the altered extracellular domain cannot recognize the cognate ligand as the other functional secretin receptors (Fig. 6).

Using cysteine-trapping method, together with the data from photoaffinity labeling and molecular modeling, the residues crucial for the interaction of secretin and secretin receptor were predicted. Consistent with previous reports (Segre \& Goldring 1993, Dong et al. 2011), the His1 of secretin is known to be essential for binding and biological activity. In this model, the highly conserved Trp284 in TM5 was proposed to interact with His1 of secretin. In addition, Asn278 in the ECL2 has also been proposed to form a hydrogen bond with the secretin residue Asp3 (Dong et al. 2012). This aspartate is highly conserved in the secretin GPCR family and is reported to be critical for the binding affinity and the biological activity of PACAP, VIP, and SCT (Dong et al. 2011). In TM4, Phe268 has been suggested to be in close contact with the Secretin Gly4 (Dong et al. 2012).

\section{Motifs for signal transduction}

When stimulated with secretin, all the characterized secretin receptors demonstrate a preferential downstream stimulation toward the cAMP to the intracellular calcium pathway (Siu et al. 2006), with the exception of teleost secretin receptors because no endogenous ligand has been identified ( $\mathrm{Ng}$ et al. 1999, Tam et al. 2011, Wang et al. 2012). This suggests that the G-protein (Gas) binding domain is well conserved in receptor evolution. Although diverged from the secretin GPCR family, secretin receptor retained the G-protein binding ability as the key regulator of signaling events.

Crucial to maintaining a functional G-protein, the His165 in TM2 and Lys312 and Leu313 in intracellular loop (ICL) 3 are conserved in all the vertebrate secretin receptors. It has been reported that the His 165 in TM2 is essential for the surface expression of secretin receptor. Mutation of this His residue (H166A or H166R) in human SCTR decreases the ligand-binding affinity, as well as cAMP response and calcium signaling, thus suggesting the poor surface expression of these mutants (Garcia et al. 2012). Lys312 and Leu313 residues in the ICL3 are important for cAMP signaling in human SCTR (Garcia et al. 2012) and also in other secretin GPCRs (Mathi et al. 1997, Couvineau et al. 2003, Marie et al. 2003).

As shown in Fig. 6, the $\mathrm{xCxR}$ motif is well conserved from fish to mammalian secretin receptors. Reported to be important for G-protein functioning (Garcia et al. 2012), mutation of the $\operatorname{Arg} 162$ residue in this motif reduces the cAMP responses without abolishing the ligand-binding ability in the rat calcitonin receptor-like receptor (Conner et al. 2006) and the rat glucagon receptor (Cypess et al. 1999). However, this mutation in human SCTR did not impair cAMP signaling, but caused a complete loss of calcium responses (Garcia et al. 2012).

In ICL2, Arg241, and Lys242 have been reported to be critical for the inositol phosphate $\left(\mathrm{IP}_{3}\right)$ signaling in many secretin GPCR members (Mathi et al. 1997, Couvineau et al. 2003, Langer et al. 2005). However, mutation analysis showed that this motif did not affect the calcium responses in human SCTR (Garcia et al. 2012). Although Lys 242 is conserved in secretin receptors, Arg241 is not conserved across different species, suggesting that this motif is not involved in controlling G-protein functioning in SCTR.

\section{$\mathrm{N}$-linked glycosylation sites}

It is well recognized that glycosylation plays an important role in cell surface receptor functions. For human SCTR, various glycosylation inhibitors were shown to reduce the secretin-stimulated cAMP response significantly. Four putative N-glycosylation sites at the extracellular domain (Asn54, Asn82, Asn88, and Asn116) of human SCTR have

Published by Bioscientifica Ltd 
been proposed. In the alignment (Fig. 6), only Asn88 is conserved in all secretin receptors. However, mutation of this residue in human SCTR did not have significant impact on the signaling and trafficking of the receptor (Pang et al. 1999). High variation was found for residue Asn82. In agreement with the mutagenesis study, this glycosylation site is not important for receptor functioning. For Asn54, mutation of this residue significantly reduces cAMP response in human SCTR. Mutation of the Asn116 residue gives contrasting findings in human SCTR. Asn-to-Leu mutation enhanced receptor function in cAMP response and Cytosensor assays, but Ser-to-Ala mutation at the same $\mathrm{N}$-glycosylation site significantly decreases the maximal responses in both cAMP and binding assays.

Among all the identified secretin receptors, human secretin could stimulate lungfish and chicken SCTRs but not $X$. laevis and zebrafish SCTRs. Relating the ligand recognition ability to the glycosylation sites, while lungfish and chicken maintain Asn54 and Asn116 in their sequences, $X$. laevis and zebrafish SCTRs are substituted with other residues at these sites. Substantiated by this observation, these two positions in the glycosylation site are critical for identifying ligand conformation in the binding process.

\section{Secretin ligand-receptor evolution}

Suggested by the comparative evolutionary analyses of all secretin and secretin receptors available at present (Fig. 7), secretin and secretin receptor emerged after the $2 \mathrm{R}$ via genome expansion. Since the earliest diverging bioactive secretin receptor was found in the sarcopterygian fish lungfish, its ability to interact with both VIP and PACAP potently suggested that secretin receptor was descended from a VPAC-like receptor before the ActinopterygiiSarcopterygii split in the vertebrate lineage. Suggested by its role in the modulation of water homeostasis in mammals, the divergence of secretin receptor prior the emergence of tetrapods could be an adaptation to the change from aquatic to terrestrial habitat (Tam et al. 2011). Despite the parallel emergence of secretin and secretin receptor as a consequence of the $2 \mathrm{R}$, they evolved via independent evolutionary trajectories until the divergence of tetrapods. While secretin receptor was retained in teleosts after teleost-specific genome duplication (TSGD), secretin was deleted. Similarly, secretin was lost in the sarcopterygian fish (e.g., lungfish) while secretin receptor was retained in the genome. It was not until the divergence of amphibians that the function of the secretin ligand-receptor pair was first established. Subsequent structural evolvement of the secretin and secretin receptor sequences gradually increased the specificity and affinity of the secretin-secretin receptor axis. Eventually, functions of VIP/PACAP and secretin have become independently regulated in mammals (Tam et al. 2011), as secretin still shows some cross-reactivity with VPAC receptors in avians.

\section{Does secretin have any physiological functions in fish?}

In fish species, secretin receptor has been identified in both lobe-finned fish (Sarcopterygii) (lungfish secretin receptor) (Tam et al. 2011) and bony-fish (Actinopterygii) (zebrafish secretin receptor) (Wang et al. 2012) lineages, although endogenous secretin has not been found (Tam et al. 2011, Wang et al. 2012, Hwang et al. 2013). Interestingly, when lungfish SCTR was tested with human and xenopus secretin and other related peptides within the PACAP-like subfamily, it was activated potently in a dose-specific manner by human PACAP and VIP peptides apart from human and xenopus secretin peptides in triggering intracellular cAMP and calcium mobilization (Tam et al. 2011). The zebrafish secretin receptor, however, was not activated by chicken secretin or chicken secretinlike peptides at $1 \mu \mathrm{M}$ (Wang et al. 2012). Because the zebrafish secretin receptor has not been tested with frog and mammalian SCT peptides, we cannot exclude the possibility that it is a bioactive receptor. However, the absence of secretin suggests that even if the fish secretin receptors are bioactive, they may act as the cognate receptor for peptides (e.g., PACAP and VIP) other than secretin.

\section{Functional emergence of secretin-secretin receptor axis in land vertebrates}

The secretin receptor isolated from $X$. laevis was shown to be highly specific to its endogenous SCT peptide in triggering intracellular cAMP and calcium mobilization (Tam et al. 2011). In a primary pancreatic ductal cell culture prepared from $R$. rugulosa, xenopus secretin was shown to be able to trigger dose-dependent intracellular cAMP accumulation (Tam et al. 2011). Taking together that the highest co-expression of SCT and SCTR has been detected in $X$. laevis intestine, it is very likely that secretin has already established its function(s) in the gastrointestinal tract in amphibians.

In avians, unlike the high specificity of secretin and its receptor in frogs, chicken secretin could also activate chicken VPAC1, VAPC2, GHRHR1, GHRHR2, and PAC1 in

Published by Bioscientifica Ltd 

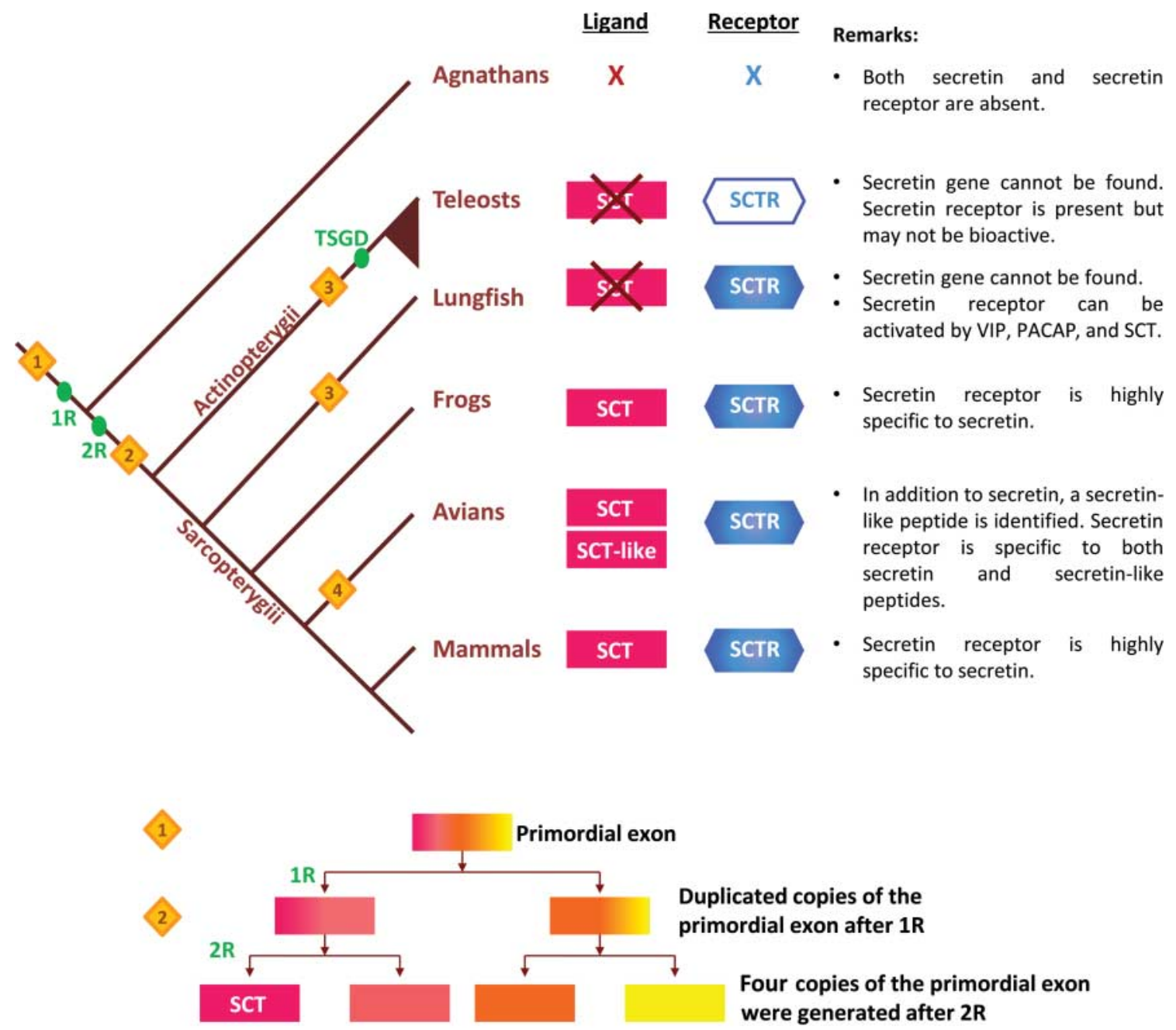

S.: Gene loss in lungfish and teleosts post $\mathbf{2 R}$

SCT SCT-like Avian-specific local exon duplication of secretin, generating two bioactive secretin peptides.

\section{Figure 7}

Summary of secretin and secretin receptors characterized at present. The hypothetical timing of the two rounds of whole-genome duplications (1R and 2R) (Ogino et al. 2009) and the teleost-specific genome duplication (TSGD) are indicated by a green dot on the phylogeny of the vertebrate lineage. Major events in the evolution of SCT are marked by a yellow diamond and explained with diagrams and description. It is hypothesized that SCT genes were deleted in teleosts and lungfish (Hwang et al. 2013). The cross represents the absence of the genes. Color-filled hexagons represent the presence of a bioactive gene while the white-filled hexagon represents the presence of a gene which may not be bioactive.

gene/genome expansion event which generated the secretin-like peptide. With a dual-ligand control mechanism and coordination with other related receptors, we postulate that the physiological functions of secretin have become more diverged but monitored in a more precise manner in avians when compared with amphibians. http://jme.endocrinology-journals.org DOI: 10.1530/JME-13-0259
(C) 2014 Society for Endocrinology Printed in Great Britain
Published by Bioscientifica Ltd 


\section{Secretin is a neuropeptide in mammals}

In humans, there is evidence that secretin could alleviate autistic symptoms (Horvath et al. 1998, Horvath 2000, Kuntz et al. 2004, Toda et al. 2004), suggesting the physiological importance of secretin in the CNS. In rat, secretin has been shown to be involved in water homeostasis by its action in the hypothalamo-neurohypophysial axis (Chu et al. 2009). Under plasma hyperosmolality conditions, secretin is released from the posterior pituitary and it stimulates vasopressin expression and release in the hypothalamus (Chu et al. 2009). It also increases the firing rate of oxytocin neurons dose dependently and exhibits excitatory effects on supraoptic nucleus vasopressin neurons (Velmurugan et al. 2010). In mouse, secretin is involved in the synaptic function, because $S C T$ knockout mice have been reported to have impairment in synaptic plasticity in the hippocampus (Yamagata et al. 2008). However, it is unclear whether secretin exerts any biological functions in the CNS in nonmammalian vertebrates at present. Suggested by the relatively low expression levels of secretin and secretin receptor in frog and chicken, secretin may have limited role in the CNS in nonmammalian vertebrates (Wang et al. 2012).

\section{Secretin serves as a gastrointestinal hormone in both nonmammalian vertebrates and mammals}

As mentioned previously, secretin shows bioactivity in frog pancreatic cells (Tam et al. 2011). This principal function of secretin was first demonstrated in dogs. Secretin stimulates the secretion of bicarbonate, water, and electrolytes from the pancreatic ductal epithelium in response to gastric acid and fatty acids in the duodenum (Meyer et al. 1970, Watanabe et al. 1986). In rat, secretin has been demonstrated to potentiate the effect of cholecystokinin in the stimulation of enzyme secretion from the pancreatic acinar cells (Rausch et al. 1985) and promotes pancreatic growth (Solomon et al. 1978, 1983, 1987).

In the duodenum, secretin facilitates the secretion of mucus, bicarbonate, and epidermal growth factor from Brunner's gland in rat (Olsen et al. 1994). In humans (Dinoso et al. 1973) and dogs (Ramirez \& Farrar 1970, Hirose et al. 1986), secretin inhibits the small intestine and colon contraction activity. Moreover, secretin has been demonstrated to inhibit the absorption of water, sodium, and glucose from dog jejunum and rat ileum (Pansu et al. 1980, Hirose et al. 1986), and increase the weight, DNA, and protein content of the rat small intestine (Hoang et al. 1988).
In stomach, secretin acts as an enterogastrone that inhibits gastric acid release and gastric emptying (Valenzuela \& Defilippi 1981, Kleibeuker et al. 1984, You \& Chey 1987, Raybould \& Holzer 1993, Jin et al. 1994). It inhibits pentagastrin-stimulated acid secretion in dogs (Chey et al. 1981), rats (Rhee et al. 1991), and humans (You \& Chey 1987). In humans (Dinoso et al. 1969) and dogs (Chey et al. 1981), secretin was reported to delay gastric emptying by inhibiting the gastric motility, in which the contraction force of the antrum is reduced by secretin. Apart from that, secretin was reported to significantly increase endogenous somatostatin in perfused rat (Chung et al. 1994) and dog stomachs (Gerber \& Payne 1996). Furthermore, secretin stimulates pepsin secretion in dogs and cats (Magee \& Nakajima 1968, Stening et al. 1969). In humans, secretin was reported to increase both pepsin and pepsinogen output of the unstimulated stomach (Walde \& Waldum 1981, Waldum et al. 1981).

\section{Secretin in other peripheral organs}

Secretin has also been reported to exert biological functions in other peripheral organs including kidney, heart, lung, and the reproductive organs. In particular, secretin has been reported to act on the proximal and distal epididymis in an autocrine and paracrine manner to control the secretion of electrolytes and water when secreted by the proximal epididymis in rat (Chow et al. 2004). Interestingly, co-expression of secretin and secretin receptor is also detected in chicken testis, suggesting that secretin may act as an autocrine/paracrine factor involved in the regulation of testis functions (Wang et al. 2012), similar to what is observed in rat (Chow et al. 2004). In ovariectomized estrogen-primed rats, secretin injection into the preoptic nucleus could increase the circadian rise of luteinizing hormone release (Kimura et al. 1987). In human, secretin has been suggested to be involved in the stimulation of ovulation as a concurrent surge of plasma secretin and serum estradiol has been observed (Holst et al. 1989a), and it inhibits prolactin release during follicular and luteal phases of the menstrual cycle (Holst et al. 1991). Also, the plasma secretin level is significantly increased from week 28 to 36 during pregnancy in human (Holst et al. 1989b). Hence, apart from the digestive system, secretin probably plays a role in the reproductive system in nonmammalian vertebrates. It would be interesting to investigate whether secretin would be involved in both the male and female reproductive systems in frogs and chickens because they utilize a different reproductive approach from mammals.

Published by Bioscientifica Ltd 
Although the moderate sequence conservation of secretin in nonmammalian vertebrates may implicate rapid functional evolution, it is possible that secretin first emerged as a gastrointestinal hormone in early vertebrates, and via the modulation of the ligand-receptor specificity, secretin becomes a pleiotropic hormone in mammals, exhibiting a wide spectrum of functions in different parts of the body.

\section{Conclusion and future perspectives}

Secretin diverged prior the Actinopterygii-Sarcopterygii split and is descended from the primordial exon that produced four paralogous genes as a result of the genome expansion (2R) in the vertebrate lineage. Its cognate receptor is proposed to have descended from VPAC-like receptors in parallel with secretin, resulting in having a copy in both lungfish and zebrafish, although their endogenous secretins were lost. Secretin and secretin receptor have gone through independent evolutionary processes despite their parallel emergence. A functional secretin-secretin receptor axis was first established with the divergence of amphibians. At present, although the physiological functions of mammalian secretin are well studied, the information on the bioactivity and functions of secretin in nonmammalian tetrapods are limited. To understand the structural and functional evolution of secretin, secretin functions in nonmammals should be further explored and studied in different vertebrate species (teleosts, lungfish, frogs, and chicken) for the next step.

\section{Declaration of interest}

The authors declare that there is no conflict of interest that could be perceived as prejudicing the impartiality of the review.

\section{Funding}

This work was supported by the Hong Kong government grants, HKU6/CRF/11G and GRF764812M to B K C C and Committee on Research and Conference Grants (CRCG) 201011159013 to L T O L.

\section{Acknowledgements}

The authors thank Dr Christopher Binny for the editing of the manuscript.

\section{References}

Bailes HJ, Trezise AE \& Collin SP 2007 The optics of the growing lungfish eye: lens shape, focal ratio and pupillary movements in Neoceratodus forsteri (Krefft, 1870). Visual Neuroscience 24 377-387. (doi:10.1017/ S0952523807070381)
Bayliss WM \& Starling EH 1902 The mechanism of pancreatic secretion. Journal of Physiology 28 325-353.

Bounjoua Y, Vandermeers A, Robberecht P, Vandermeers-Piret MC \& Christophe J 1991 Purification and amino acid sequence of vasoactive intestinal peptide, peptide histidine isoleucinamide and secretin from the ovine small intestine. Regulatory Peptides 32 169-179. (doi:10.1016/ 0167-0115(91)90044-H)

Bourgault S, Vaudry D, Segalas-Milazzo I, Guilhaudis L, Couvineau A, Laburthe M, Vaudry H \& Fournier A 2009 Molecular and conformational determinants of pituitary adenylate cyclase-activating polypeptide (PACAP) for activation of the PAC1 receptor. Journal of Medicinal Chemistry 52 3308-3316. (doi:10.1021/jm900291j)

Buscail L, Cauvin A, Gourlet P, Gossen D, De Neef P, Rathe J, Robberecht P, Vandermeers-Piret MC, Vandermeers A \& Christophe J 1990 Purification and amino acid sequence of vasoactive intestinal peptide, peptide histidine isoleucinamide (1-27) and secretin from the small intestine of guinea pig. Biochimica et Biophysica Acta 1038 355-359. (doi:10.1016/0167-4838(90)90248-E)

Cardoso JC, Pinto VC, Vieira FA, Clark MS \& Power DM 2006 Evolution of secretin family GPCR members in the metazoa. BMC Evolutionary Biology 6 108. (doi:10.1186/1471-2148-6-108)

Cardoso JC, Vieira FA, Gomes AS \& Power DM 2010 The serendipitous origin of chordate secretin peptide family members. BMC Evolutionary Biology 10 135. (doi:10.1186/1471-2148-10-135)

Carlquist M, Jornvall H \& Mutt V 1981 Isolation and amino acid sequence of bovine secretin. FEBS Letters 127 71-74. (doi:10.1016/00145793(81)80343-2)

Carlquist M, Joernvall H, Forssmann WG, Thulin L, Johansson C \& Mutt V 1985 Human secretin is not identical to the porcine/bovine hormone. IRCS Medical Science 13 217-218.

Chan KW, Yu KL, Rivier J \& Chow BK 1998 Identification and characterization of a receptor from goldfish specific for a teleost growth hormone-releasing hormone-like peptide. Neuroendocrinology 68 44-56. (doi:10.1159/000054349)

Chey WY, Kim MS, Lee KY \& Chang TM 1981 Secretin is an enterogastrone in the dog. American Journal of Physiology 240 G239-G244.

Chow BK, Yuen TT \& Chan KW 1997 Molecular evolution of vertebrate VIP receptors and functional characterization of a VIP receptor from goldfish Carassius auratus. General and Comparative Endocrinology 105 176-185. (doi:10.1006/gcen.1996.6818)

Chow BK, Cheung KH, Tsang EM, Leung MC, Lee SM \& Wong PY 2004 Secretin controls anion secretion in the rat epididymis in an autocrine/paracrine fashion. Biology of Reproduction 70 1594-1599. (doi:10.1095/biolreprod.103.024257)

Chu JY, Lee LT, Lai CH, Vaudry H, Chan YS, Yung WH \& Chow BK 2009 Secretin as a neurohypophysial factor regulating body water homeostasis. PNAS 106 15961-15966. (doi:10.1073/pnas.0903695106)

Chung I, Li P, Lee K, Chang T \& Chey WY 1994 Dual inhibitory mechanism of secretin action on acid secretion in totally isolated, vascularly perfused rat stomach. Gastroenterology 107 1751-1758.

Conner AC, Simms J, Howitt SG, Wheatley M \& Poyner DR 2006 The second intracellular loop of the calcitonin gene-related peptide receptor provides molecular determinants for signal transduction and cell surface expression. Journal of Biological Chemistry 281 1644-1651. (doi:10.1074/jbc.M510064200)

Couvineau A, Lacapere JJ, Tan YV, Rouyer-Fessard C, Nicole P \& Laburthe M 2003 Identification of cytoplasmic domains of hVPAC1 receptor required for activation of adenylyl cyclase. Crucial role of two charged amino acids strictly conserved in class II G protein-coupled receptors. Journal of Biological Chemistry 278 24759-24766. (doi:10.1074/jbc. M301916200)

Cypess AM, Unson CG, Wu CR \& Sakmar TP 1999 Two cytoplasmic loops of the glucagon receptor are required to elevate cAMP or intracellular calcium. Journal of Biological Chemistry 274 19455-19464. (doi:10.1074/ jbc.274.27.19455) 
Dinoso V, Chey WY, Hendricks J \& Lorber SH 1969 Intestinal mucosal hormones and motor function of the stomach in man. Journal of Applied Physiology 26 326-329.

Dinoso VP Jr, Meshkinpour H, Lorber SH, Gutierrez JG \& Chey WY 1973 Motor responses of the sigmoid colon and rectum to exogenous cholecystokinin and secretin. Gastroenterology 65 438-444.

Dong M, Le A, Te JA, Pinon DI, Bordner AJ \& Miller LJ 2011 Importance of each residue within secretin for receptor binding and biological activity. Biochemistry 50 2983-2993. (doi:10.1021/bi200133u)

Dong M, Xu X, Ball AM, Makhoul JA, Lam PC, Pinon DI, Orry A, Sexton PM, Abagyan R \& Miller LJ 2012 Mapping spatial approximations between the amino terminus of secretin and each of the extracellular loops of its receptor using cysteine trapping. FASEB Journal 26 5092-5105. (doi:10.1096/fj.12-212399)

Furness SG, Wootten D, Christopoulos A \& Sexton PM 2012 Consequences of splice variation on Secretin family $G$ protein-coupled receptor function. British Journal of Pharmacology 166 98-109. (doi:10.1111/j. 1476-5381.2011.01571.x)

Gallwitz B, Witt M, Paetzold G, Morys-Wortmann C, Zimmermann B, Eckart K, Folsch UR \& Schmidt WE 1994 Structure/activity characterization of glucagon-like peptide-1. European Journal of Biochemistry $\mathbf{2 2 5}$ 1151-1156. (doi:10.1111/j.1432-1033.1994.1151b.x)

Garcia GL, Dong M \& Miller LJ 2012 Differential determinants for coupling of distinct $\mathrm{G}$ proteins with the class B secretin receptor. American Journal of Physiology. Cell Physiology 302 C1202-C1212. (doi:10.1152/ ajpcell.00273.2011)

Gerber JG \& Payne NA 1996 Secretin inhibits canine gastric acid secretion in response to pentagastrin by modulating gastric histamine release. Journal of Pharmacology and Experimental Therapeutics 279 718-723.

Gossen D, Buscail L, Cauvin A, Gourlet P, De Neef P, Rathe J, Robberecht P, Vandermeers-Piret MC, Vandermeers A \& Christophe J 1990 Amino acid sequence of VIP, PHI and secretin from the rabbit small intestine. Peptides 11 123-128. (doi:10.1016/0196-9781(90)90120-T)

Gourlet P, Woussen-Colle MC, Robberecht P, de Neef P, Cauvin A, Vandermeers-Piret MC, Vandermeers A \& Christophe J 1991 Structural requirements for the binding of the pituitary adenylate-cyclaseactivating peptide to receptors and adenylate-cyclase activation in pancreatic and neuronal membranes. European Journal of Biochemistry 195 535-541. (doi:10.1111/j.1432-1033.1991.tb15734.x)

Hirose S, Shimazaki K \& Hattori N 1986 Effect of secretin and caerulein on the absorption of water, electrolytes and glucose from the jejunum of dogs. Digestion 35 205-210. (doi:10.1159/000199369)

Hoang HD, Wood JG, Bussjaeger LJ \& Solomon TE 1988 Interaction of neurotensin with caerulein or secretin on digestive tract growth in rats. Regulatory Peptides 22 275-284. (doi:10.1016/0167-0115(88)90040-7)

Holst N, Jenssen TG, Burhol PG, Haug E \& Forsdahl F 1989a Plasma gastrointestinal hormones during spontaneous and induced menstrual cycles. Journal of Clinical Endocrinology and Metabolism 68 1160-1166. (doi:10.1210/jcem-68-6-1160)

Holst N, Jenssen TG, Burhol PG \& Maltau JM 1989b Plasma secretin concentrations during normal human pregnancy, delivery, and postpartum. British Journal of Obstetrics and Gynaecology 96 424-427. (doi:10.1111/j.1471-0528.1989.tb02416.x)

Holst N, Jenssen TG, Burhol PG \& Haug E 1991 Prolactin response to secretin during the spontaneous menstrual cycle in women. Gynecologic and Obstetric Investigation 31 37-41. (doi:10.1159/000293097)

Horvath K 2000 Secretin treatment for autism. New England Journal of Medicine 3421216 author reply 1218. (doi:10.1056/ NEJM200004203421614)

Horvath K, Stefanatos G, Sokolski KN, Wachtel R, Nabors L \& Tildon JT 1998 Improved social and language skills after secretin administration in patients with autistic spectrum disorders. Journal of the Association for Academic Minority Physicians 9 9-15.

Hwang JI, Moon MJ, Park S, Kim DK, Cho EB, Ha N, Son GH, Kim K, Vaudry $\mathrm{H} \&$ Seong JY 2013 Expansion of secretin-like G protein-coupled receptors and their peptide ligands via local duplications before and after two rounds of whole-genome duplication. Molecular Biology and Evolution 30 1119-1130. (doi:10.1093/molbev/mst031)

Irwin DM 2001 Molecular evolution of proglucagon. Regulatory Peptides 98 1-12. (doi:10.1016/S0167-0115(00)00232-9)

Jin HO, Lee KY, Chang TM, Chey WY \& Dubois A 1994 Secretin: a physiological regulator of gastric emptying and acid output in dogs. American Journal of Physiology 267 G702-G708.

Jorpes JE \& Mutt V 1961 The gastrointestinal hormones, secretin and cholecystokinin-pancreozymin. Annals of Internal Medicine 55 395-405. (doi:10.7326/0003-4819-55-3-395)

Kimura F, Mitsugi N, Arita J, Akema T \& Yoshida K 1987 Effects of preoptic injections of gastrin, cholecystokinin, secretin, vasoactive intestinal peptide and PHI on the secretion of luteinizing hormone and prolactin in ovariectomized estrogen-primed rats. Brain Research 410 315-322. (doi:10.1016/0006-8993(87)90330-1)

Kleibeuker JH, Eysselein VE, Maxwell VE \& Walsh JH 1984 Role of endogenous secretin in acid-induced inhibition of human gastric function. Journal of Clinical Investigation 73 526-532. (doi:10.1172/ JCI111239)

Kopin AS, Wheeler MB, Nishitani J, McBride EW, Chang TM, Chey WY \& Leiter AB 1991 The secretin gene: evolutionary history, alternative splicing, and developmental regulation. PNAS 88 5335-5339. (doi:10.1073/pnas.88.12.5335)

Kuntz A, Clement HW, Lehnert W, van Calker D, Hennighausen K, Gerlach M \& Schulz E 2004 Effects of secretin on extracellular amino acid concentrations in rat hippocampus. Journal of Neural Transmission 111 931-939. (doi:10.1007/s00702-003-0082-y)

Laburthe M, Couvineau A, Gaudin P, Maoret JJ, Rouyer-Fessard C \& Nicole P 1996 Receptors for VIP, PACAP, secretin, GRF, glucagon, GLP-1, and other members of their new family of G protein-linked receptors: structure-function relationship with special reference to the human VIP-1 receptor. Annals of the New York Academy of Sciences $\mathbf{8 0 5}$ 94-109. (doi:10.1111/j.1749-6632.1996.tb17476.x)

Langer I, Langlet C \& Robberecht P 2005 Effect of inactivating mutations on phosphorylation and internalization of the human VPAC2 receptor. Journal of Molecular Endocrinology 34 405-414. (doi:10.1677/jme.1. 01717)

Lee LT, Siu FK, Tam JK, Lau IT, Wong AO, Lin MC, Vaudry H \& Chow BK 2007 Discovery of growth hormone-releasing hormones and receptors in nonmammalian vertebrates. PNAS 104 2133-2138. (doi:10.1073/ pnas.0611008104)

Magee DF \& Nakajima S 1968 Stimulatory action of secretin on gastric pepsin secretion. Experientia 24 689-690. (doi:10.1007/BF02138315)

Marie JC, Rouyer-Fessard C, Couvineau A, Nicole P, Devaud H, El Benna J \& Laburthe M 2003 Serine 447 in the carboxyl tail of human VPAC1 receptor is crucial for agonist-induced desensitization but not internalization of the receptor. Molecular Pharmacology 64 1565-1574. (doi:10.1124/mol.64.6.1565)

Mathi SK, Chan Y, Li X \& Wheeler MB 1997 Scanning of the glucagon-like peptide-1 receptor localizes $\mathrm{G}$ protein-activating determinants primarily to the $\mathrm{N}$ terminus of the third intracellular loop. Molecular Endocrinology 11 424-432. (doi:10.1210/mend.11.4.9913)

Meyer JH, Way LW \& Grossman MI 1970 Pancreatic bicarbonate response to various acids in duodenum of the dog. American Journal of Physiology 219 964-970.

Modlin IM \& Kidd M 2001 Ernest Starling and the discovery of secretin. Journal of Clinical Gastroenterology 32 187-192. (doi:10.1097/00004836200103000-00001)

Mutt V, Jorpes JE \& Magnusson S 1970 Structure of porcine secretin. The amino acid sequence. European Journal of Biochemistry 15 513-519. (doi:10.1111/j.1432-1033.1970.tb01034.x)

Ng SS, Pang RT, Chow BK \& Cheng CH 1999 Real-time evaluation of human secretin receptor activity using cytosensor microphysiometry. Journal of Cellular Biochemistry 72 517-527. (doi:10.1002/(SICI)10974644(19990315)72:4<517::AID-JCB7>3.0.CO;2-1) 
Ng SS, Yung WH \& Chow BK 2002 Secretin as a neuropeptide. Molecular Neurobiology 26 97-107. (doi:10.1385/MN:26:1:097)

$\mathrm{Ng}$ SY, Lee LT \& Chow BK 2010 Insights into the evolution of proglucagonderived peptides and receptors in fish and amphibians. Annals of the New York Academy of Sciences 1200 15-32. (doi:10.1111/j.1749-6632. 2010.05505.x)

$\mathrm{Ng}$ SY, Lee LT \& Chow BK 2012 Receptor oligomerization: from early evidence to current understanding in class B GPCRs. Frontiers in Endocrinology 3175.

Nilsson A, Carlquist M, Jornvall H \& Mutt V 1980 Isolation and characterization of chicken secretin. European Journal of Biochemistry 112 383-388. (doi:10.1111/j.1432-1033.1980.tb07216.x)

Ogino Y, Katoh H, Kuraku S \& Yamada G 2009 Evolutionary history and functional characterization of androgen receptor genes in jawed vertebrates. Endocrinology 150 5415-5427. (doi:10.1210/en.2009-0523)

Ohno S 1970 Evolution by Gene Duplication. New York: Springer-Verlag.

Olsen PS, Kirkegaard P, Poulsen SS \& Nexo E 1994 Effect of secretin and somatostatin on secretion of epidermal growth factor from Brunner's glands in the rat. Digestive Diseases and Sciences 39 2186-2190. (doi:10.1007/BF02090369)

Pang RT, Ng SS, Cheng CH, Holtmann MH, Miller LJ \& Chow BK 1999 Role of N-linked glycosylation on the function and expression of the human secretin receptor. Endocrinology 140 5102-5111. (doi:10.1210/endo. 140.11.7134)

Pansu D, Bosshard A, Dechelette MA \& Vagne M 1980 Effect of pentagastrin, secretin and cholecystokinin on intestinal water and sodium absorption in the rat. Digestion 20 201-206. (doi:10.1159/ 000198440)

Ramirez M \& Farrar JT 1970 The effect of secretin and cholecystokininpancreozymin on the intraluminal pressure of the jejunum in the unanesthetized dog. American Journal of Digestive Diseases 15 539-544. (doi:10.1007/BF02238114)

Rausch U, Vasiloudes P, Rudiger K \& Kern HF 1985 In-vivo stimulation of rat pancreatic acinar cells by infusion of secretin. I. Changes in enzyme content, pancreatic fine structure and total rate of protein synthesis. Cell Tissue Research 242 633-639. (doi:10.1007/BF00225430)

Raybould HE \& Holzer H 1993 Secretin inhibits gastric emptying in rats via a capsaicin-sensitive vagal afferent pathway. European Journal of Pharmacology 250 165-167. (doi:10.1016/0014-2999(93)90636-V)

Rhee JC, Chang TM, Lee KY, Jo YH \& Chey WY 1991 Mechanism of oleic acid-induced inhibition on gastric acid secretion in rats. American Journal of Physiology 260 G564-G570.

Segre GV \& Goldring SR 1993 Receptors for secretin, calcitonin, parathyroid hormone (PTH)/PTH-related peptide, vasoactive intestinal peptide, glucagonlike peptide 1, growth hormone-releasing hormone, and glucagon belong to a newly discovered G-protein-linked receptor family. Trends in Endocrinology and Metabolism 4 309-314. (doi:10.1016/ 1043-2760(93)90071-L)

Sherwood NM, Krueckl SL \& McRory JE 2000 The origin and function of the pituitary adenylate cyclase-activating polypeptide (PACAP)/glucagon superfamily. Endocrine Reviews 21 619-670.

Shinomura Y, Eng J \& Yalow RS 1987 Dog secretin: sequence and biologic activity. Life Sciences 41 1243-1248. (doi:10.1016/00243205(87)90202-5)

Siu FK, Lam IP, Chu JY \& Chow BK 2006 Signaling mechanisms of secretin receptor. Regulatory Peptides 137 95-104. (doi:10.1016/j.regpep.2006. 02.011)
Solomon TE, Petersen H, Elashoff J \& Grossman MI 1978 Interaction of caerulein and secretin on pancreatic size and composition in rat. American Journal of Physiology 235 E714-E719.

Solomon TE, Vanier M \& Morisset J 1983 Cell site and time course of DNA synthesis in pancreas after caerulein and secretin. American Journal of Physiology 245 G99-105.

Solomon TE, Morisset J, Wood JG \& Bussjaeger LJ 1987 Additive interaction of pentagastrin and secretin on pancreatic growth in rats. Gastroenterology 92 429-435.

Steinke D, Hoegg S, Brinkmann H \& Meyer A 2006 Three rounds (1R/2R/3R) of genome duplications and the evolution of the glycolytic pathway in vertebrates. BMC Biology 4 16. (doi:10.1186/1741-7007-4-16)

Stening GF, Johnson LR \& Grossman MI 1969 Effect of secretin on acid and pepsin secretion in cat and dog. Gastroenterology 56 468-475.

Tam JK, Lau KW, Lee LT, Chu JY, Ng KM, Fournier A, Vaudry H \& Chow BK 2011 Origin of secretin receptor precedes the advent of tetrapoda: evidence on the separated origins of secretin and orexin. PLOS ONE 6 e19384. (doi:10.1371/journal.pone.0019384)

Toda Y, Mori K, Hashimoto T, Miyazaki M \& Kuroda Y 2004 Efficacy of secretin for the treatment of autism. No To Hattatsu. Brain and Development 36 289-295.

Valenzuela JE \& Defilippi C 1981 Inhibition of gastric emptying in humans by secretion, the octapeptide of cholecystokinin, and intraduodenal fat. Gastroenterology 81 898-902.

Velmurugan S, Brunton PJ, Leng G \& Russell JA 2010 Circulating secretin activates supraoptic nucleus oxytocin and vasopressin neurons via noradrenergic pathways in the rat. Endocrinology 151 2681-2688. (doi:10.1210/en.2009-1440)

Walde NH \& Waldum HL 1981 The effect of secretin in physiological doses on serum group I pepsinogens (PG I) in man. Hepatogastroenterology 28 322-323.

Waldum HL, Walde N \& Burhol PG 1981 The effect of secretin on gastric $\mathrm{H}+$ and pepsin secretion and on urinary electrolyte excretion in man. Scandinavian Journal of Gastroenterology 16 999-1004. (doi:10.3109/ 00365528109181018)

Wang Y, Huang G, Li J, Meng F, He X \& Leung FC 2012 Characterization of chicken secretin (SCT) and secretin receptor (SCTR) genes: a novel secretin-like peptide (SCT-LP) and secretin encoded in a single gene. Molecular and Cellular Endocrinology 348 270-280. (doi:10.1016/j.mce. 2011.09.012)

Watanabe S, Chey WY, Lee KY \& Chang TM 1986 Secretin is released by digestive products of fat in dogs. Gastroenterology 90 1008-1017.

Whitmore TE, Holloway JL, Lofton-Day CE, Maurer MF, Chen L, Quinton TJ, Vincent JB, Scherer SW \& Lok S 2000 Human secretin (SCT): gene structure, chromosome location, and distribution of mRNA. Cytogenetics and Cell Genetics 90 47-52. (doi:10.1159/ 000015658)

Wray V, Nokihara K \& Naruse S 1998 Solution structure comparison of the VIP/PACAP family of peptides by NMR spectroscopy. Annals of the New York Academy of Sciences 865 37-44. (doi:10.1111/j.1749-6632.1998. tb11160.x)

Yamagata T, Urano H, Weeber EJ, Nelson DL \& Nishijima I 2008 Impaired hippocampal synaptic function in secretin deficient mice. Neuroscience 154 1417-1422. (doi:10.1016/j.neuroscience.2008.04.037)

You CH \& Chey WY 1987 Secretin is an enterogastrone in humans. Digestive Diseases and Sciences 32 466-471. (doi:10.1007/BF01296028)

Received in final form 12 March 2014

Accepted 21 March 2014 http://jme.endocrinology-journals.org DOI: 10.1530/JME-13-0259
() 2014 Society for Endocrinology Printed in Great Britain
Published by Bioscientifica Ltd 